\title{
Comparison of two doses of cimetidine and placebo in the treatment of duodenal ulcer: a multicentre trial ${ }^{1}$
}

SUMMARY Endoscopy, clinical assessment, and laboratory studies were used to compare, in a doubleblind multicentre trial, the effects on patients with duodenal ulceration of treatment for four weeks by either placebo or $1 \mathrm{~g}$ /day cimetidine, or $2 \mathrm{~g}$ /day cimetidine. Ulcer healing occurred in $28 \%$ of patients on placebo, $61 \%$ of patients on $1 \mathrm{~g}$ cimetidine daily, and $70 \%$ of patients on $2 \mathrm{~g}$ cimetidine daily. Thus cimetidine conferred an advantage over placebo, but the effects of the two doses of cimetidine were not shown to be different. Symptomatic improvement in patients given cimetidine was usually marked and occurred early. Patients were required to report all symptoms, but the only symptom which might have been caused by cimetidine was headache in $5 \%$ of patients. Biochemical studies showed significant (though slight) rises in serum uric acid, and serum creatinine but no significant changes occurred in the serum levels of liver enzymes. This study confirms that $1 \mathrm{~g}$ is a suitable daily dose of cimetidine for the treatment of duodenal ulceration.

The choice of dosage for cimetidine was based on the idea that operations for duodenal ulceration are curative because they reduce the capacity of the stomach to secrete acid and pepsin. The idea was to choose doses of cimetidine which would mimic the effects of surgery on acid secretion; perhaps they would also allow ulcers to heal. The present study was therefore designed to compare the healing of uncomplicated duodenal ulcers in patients treated with placebo or with cimetidine in a dose of either 1 or $2 \mathrm{~g}$ per day. Pre-clinical and early clinical studies had suggested that the lower dose of cimetidine would be effective.

It was known, for example, that a single dose of $400 \mathrm{mg}$ cimetidine at bed time produced as much inhibition of nocturnal acid secretion as did a dose of $800 \mathrm{mg}$ (Blackwood and Northfield, 1977). Also, 200 mg taken six-hourly had as much effect during the daytime as did 400 mg six-hourly(Pounder et al., 1975). This suggested that $200 \mathrm{mg}$ three times a day and 400 $\mathrm{mg}$ at bed time would give optimal suppression of acid

\footnotetext{
${ }^{1}$ Participants: K. D. Bardhan, D. M. Saul (Rotherham Hospital, Rotherham); J. L. Edwards, P. M. Smith (Llandough Hospital, Penarth); M. Fettes, J. Forrest, R. C. Heading, R. F. A. Logan (Royal Infirmary, Edinburgh); M. W. Dronfield, M. J. Langman (City Hospital, Nottingham); W. Larkworthy (R.A.F. Hospital, Nocton Hall, Lincs.); S. J. Haggie, J. H. Wyllie $^{2}$ (University College Hospital, London); C. Corbett, $\mathrm{H}$. L. Duthie, I. V. Fussey, C. D. Holdsworth (Royal Infirmary, Sheffield); and G. V. Balmforth, T. Maruyama (Royal Infirmary, Doncaster).

${ }^{2}$ Correspondence to Professor Wyllie.

Received for publication 22 June 1978
}

secretion throughout the 24 hours. In addition, we tested double these doses, so giving $2 \mathrm{~g}$ /day cimetidine-the largest dose which has been given to a substantial group of duodenal ulcer patients.

To assess the relative merits of the two doses of cimetidine we considered it necessary to have information about the effect of a zero dose; so a placebo group was designed to contain $25 \%$ of the patients, the others being evenly distributed between the two treatment groups. Randomisation was carried out by Smith, Kline and French Laboratories Ltd, who provided each centre with tablets in code-numbered containers. This experimental design was accepted by local ethical committees. The trial was started in March 1976 and was completed about a year later.

\section{Methods}

\section{PATIENTS}

The 200 patients admitted to the trial were all adults with uncomplicated duodenal ulcers seen at endoscopy less than seven days (and usually about two days) before the start of the trial. Patients were excluded who were known to have other gastrointestinal disease or who had undergone ulcer surgery apart from simple suture of a perforation. Pregnancy and lactation were also contraindications to entry to the trial. With these provisos, the series of patients was essentially consecutive. Patients were randomly allocated in a double-blind manner to one of three treatments; cimetidine in a dose of $200 \mathrm{mg}$ three times a day after meals and $400 \mathrm{mg}$ at bedtime 
( $1 \mathrm{~g}$ daily), $400 \mathrm{mg}$ three times a day after meals and $800 \mathrm{mg}$ at bedtime ( $2 \mathrm{~g}$ daily), or placebo. The tablets for all three treatments appeared identical. Patients were also given a known number of unmarked antacid tablets (actually Rennies, Nicholas Labs) to be taken as required for relief of pain, so conventional antacid therapy was not denied to patients in the placebo group. All other therapy for peptic ulcer was withdrawn. No guidance was offered about diet or smoking.

Using diary cards, the patients kept a daily record of pain and antacid consumption. They were seen after two and four weeks. At each attendance the patients were interviewed and examined, diary cards were scrutinised, and tablet consumption was checked by inquiry. (Counts of returned tablets were planned but many patients did not co-operate; we suspect they hoarded spare cimetidine tablets.) In six of the centres patients also kept diaries for one week before entering the trial.

At each attendance blood was taken for routine analyses, and urine was examined. Within 48 hours of stopping treatment endoscopy was repeated, usually by the original endoscopist. Ulcer healing was rigidly defined as complete disappearance of all ulcers and erosions. At both endoscopies a note was also made of duodenitis. This was defined as visual evidence of inflammation and was assessed on four-point scales for severity (none, mild, moderate, severe) and for extent (none, localised to ulcer, more than one area, and throughout the duodenal cap.) Since no objective criteria of duodenitis could be supplied, these assessments were subjective and it is unlikely that different observers applied the same criteria. It is possible that knowledge of clinical progress might bias the judgement of endoscopists, so we tried to arrange for clinical assessment to be done by an observer who was not the endoscopist. However, this was not usually possible and in any case it could not be relied on completely to remove bias. So, although the trial was double-blind in the sense that neither patients nor observers knew which of the three regimes applied in a particular case, it was impracticable to remove all possibility of bias.

Table 1 shows the allocation to different treatments of the patients who entered the trial, and data relating to those who completed it. The randomisation procedure successfully prevented significant differences between the groups. Patients in the three treatment groups were also shown not to differ with regard to smoking history, alcohol consumption, whether the ulcer was single or multiple, and incidence of pain by day and by night in the week before entry to the study. Also, the 20 patients excluded for reasons detailed below the table were randomly distributed between the groups. The different
Table 1 Allocation of patients to trial

\begin{tabular}{|c|c|c|c|c|c|c|}
\hline \multirow{2}{*}{$\begin{array}{l}\text { Daily dose } \\
\text { of cimetidine } \\
(\text { g/day })\end{array}$} & \multirow{2}{*}{$\begin{array}{l}\text { Entered } \\
\text { trial }\end{array}$} & \multirow{2}{*}{$\begin{array}{l}\text { Completed } \\
\text { trial }\end{array}$} & \multirow{2}{*}{$\frac{\operatorname{Sex}}{M F}$} & \multirow{2}{*}{$\begin{array}{l}\text { Mean } \\
\text { age } \\
(y r\end{array}$} & \multicolumn{2}{|c|}{ Mean duration of } \\
\hline & & & & & $\begin{array}{l}\text { Ulcer } \\
\text { disease } \\
(y r)\end{array}$ & $\begin{array}{l}\text { Current } \\
\text { relapse } \\
(m t h)\end{array}$ \\
\hline $\begin{array}{l}0 \\
1 \\
2\end{array}$ & $\begin{array}{l}50 \\
78 \\
72\end{array}$ & $\begin{array}{l}46 \\
70 \\
64\end{array}$ & & $\begin{array}{ll}7 & 40 \cdot 9 \\
2 & 44 \cdot 6 \\
6 & 43 \cdot 7\end{array}$ & $\begin{array}{l}9 \cdot 0 \\
8 \cdot 8 \\
7 \cdot 5\end{array}$ & $\begin{array}{l}6 \cdot 3 \\
5 \cdot 4 \\
5 \cdot 2\end{array}$ \\
\hline
\end{tabular}

Of four patients on placebo who failed to complete the trial, two had increasing symptoms, one defaulted, and one declined second endoscopy. Similarly, of eight patients on $1 \mathrm{~g} /$ day of cimetidine, two had persisting symptoms, five defaulted or did not comply with instructions, and one had only three weeks' treatment. All eight patients on $2 \mathrm{~g}$ /day cimetidine who did not complete the trial were excluded for default or failure to comply with instructions.

centres each contributed 15 to 26 patients to the final analysis, except Rotherham (52 patients) and one other centre (nine patients).

\section{Results}

ULCER HEALING AND DUODENITIS

Table 2 shows that there was complete healing of ulcers in $28 \%$ of patients on placebo, $61 \%$ of patients on $1 \mathrm{~g}$ cimetidine daily, and $70 \%$ of patients on $2 \mathrm{~g}$ cimetidine daily. Both treatment groups showed a highly significant improvement over the placebo group, but there was no significant difference between ulcer healing on different doses of cimetidine. Nor was there any difference between the healing rates for single and multiple duodenal ulcers.

The data on duodenitis was clearly not so satisfactory as that for ulceration. The scores for 'severity' and 'extent' were identical in $64 \%$ of pre-trial endoscopies and they differed by only 1 point in $30 \%$. So we felt justified in combining the scores (by addition) to give a total score in the range $0-6$. It was then obvious that the mean score obtained at the pre-trial endoscopy varied from $4 \cdot 84 \pm 0 \cdot 15$ (SEM) in one centre to $2.00 \pm 0.50$ in another; the data seemed unsuitable for numerical treatment. Accordingly, we have considered only changes in the total score, classified as 'better' or 'same or worse'. When this was done, it could be seen that improvement in duodenitis was associated with ulcer healing and

Table 2 Healing of duodenal ulcers

\begin{tabular}{llll}
\hline $\begin{array}{l}\text { Daily dose of } \\
\text { cimetidine } \\
(g / \text { day })\end{array}$ & Ulcers healed & Total treated & \\
\hline 0 & 13 & 46 & \} \\
1 & 43 & 70 & $\left\{\begin{array}{l}x^{2}=10.94 \\
P<0.001 \\
\chi^{2}=0.81 \\
\text { NS }\end{array}\right.$ \\
\hline
\end{tabular}


Table 3 Association between cimetidine therapy, ulcer healing and improvement in duodenitis

\begin{tabular}{lccc}
\hline & Placebo & \multicolumn{2}{c}{ Cimetidine } \\
\cline { 3 - 4 } & & 1 g/day & 2 glday \\
\hline Duodenitis better & 3 & 30 & 18 \\
Ulcer healed & 2 & 7 & 6 \\
Not healed & 5 & 8 & 17 \\
Duodenitis same or worse & & 11 & 9 \\
Ulcer healed & 22 & & \\
Not healed & &
\end{tabular}

From which one may extract tables to show associations between cimetidine therapy and ulcer healing $\left(x^{2}=17 \cdot 74\right)$, cimetidine therapy and improvement in duodenitis $\left(x^{2}=15.67\right)$, ulcer healing and improvement in duodenitis $\left(x^{2}=16.57\right)$. In the 73 patients whose ulcers healed on cimetidine the data suggest that duodenitis improved more frequently on the lower dose of cimetidine $\left(x^{2}=4.96, \mathrm{p}<0.05\right)$.

with the administration of cimetidine (Table 3). Complete data were available for only 138 patients.

SYMPTOMATIC RESPONSE

Patients treated with cimetidine had significantly less pain than those receiving placebo throughout the trial. Figure 1 shows the mean number of days and nights ( \pm standard errors) on which pain occurred in each of five weeks, starting one week before the trial began. There was no difference between the groups initially; but paired-sample $t$ tests showed that the reduction in incidence of pain on the placebo was not significant, whereas on both doses of cimetidine it was apparent in the first week of treatment $(P<0.005)$ and remained so on subsequent weeks $(P<0.001)$. On the other hand, 2-sample $t$ tests showed that at no stage did a significant difference emerge between the results with $1 \mathrm{~g} /$ day cimetidine and those with $2 \mathrm{~g} /$ day.

Patients receiving cimetidine took significantly fewer antacid tablets than those given placebo each week throughout the trial except in the first week among patients given $1 \mathrm{~g}$ cimetidine daily; but antacid consumption was not well correlated with

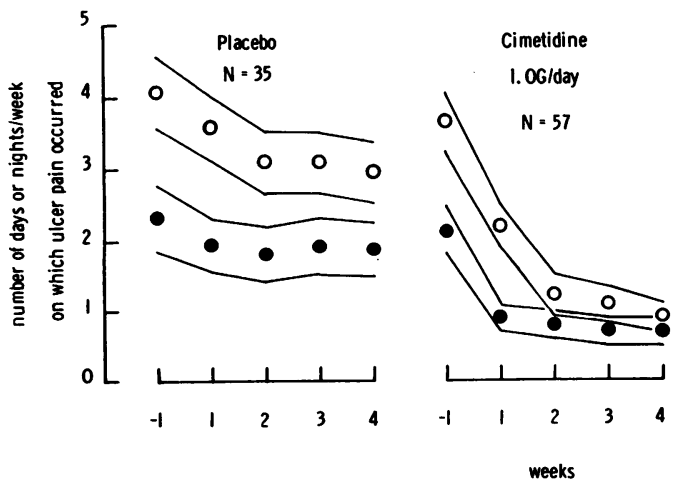

pain. This is shown in Fig. 2 which plots, for each patient, the number of days on which pain occurred against total antacid consumption.

No differences in ulcer healing rates emerged when the patients were grouped according to sex, age, total duration of peptic ulcer symptoms, duration of relapse leading to inclusion in the trial, smoking, or alcohol consumption. This was true whether the patients had cimetidine or placebo. Table 4 illustrates this for smoking.

The association between ulcer healing and complete relief of pain was, as might be expected, very significant (Table 5); but it was not absolute, showing that factors other than ulcer healing are important for relief of pain.

UNWANTED SYMPTOMS

Seventeen patients on placebo reported 30 symptoms

Table 4 Smoking history, ulcer healing, and complete relief of symptoms at the end of the trial

\begin{tabular}{|c|c|c|c|c|c|c|}
\hline & \multicolumn{3}{|c|}{$\begin{array}{l}\text { Patients with ulcers } \\
\text { healed }\end{array}$} & \multicolumn{3}{|c|}{$\begin{array}{l}\text { Patients becoming } \\
\text { asymptomatic }\end{array}$} \\
\hline & Placebo & $C I$ & $C 2$ & Placebo & $C 1$ & $C 2$ \\
\hline $\begin{array}{l}\text { Smokers } \\
\text { Non-smokers }\end{array}$ & $\begin{array}{l}8 / 33 \\
5 / 13\end{array}$ & $\begin{array}{l}30 / 50 \\
12 / 20\end{array}$ & $\begin{array}{r}31 / 44 \\
4 / 20\end{array}$ & $\begin{array}{r}12 / 27 \\
8 / 11\end{array}$ & $\begin{array}{l}34 / 41 \\
12 / 16\end{array}$ & $\begin{array}{l}27 / 33 \\
11 / 16\end{array}$ \\
\hline
\end{tabular}

Table 5 Association between complete relief of ulcer pain and healing of ulcer

\begin{tabular}{|c|c|c|c|c|c|}
\hline & \multicolumn{5}{|l|}{ Ulcer } \\
\hline & $\begin{array}{l}\text { Healed } \\
\text { (no.) }\end{array}$ & $(\%)$ & $\begin{array}{l}\text { Not } \\
\text { (no.) }\end{array}$ & (\%) & $\begin{array}{l}\text { Total } \\
\text { (no.) }\end{array}$ \\
\hline $\begin{array}{l}\text { Pain } \\
\text { Absent } \\
\text { Present } \\
\text { Total }\end{array}$ & $\begin{array}{r}61 \\
40 \\
101\end{array}$ & $\begin{array}{l}34 \\
22\end{array}$ & $\begin{array}{l}31 \\
47 \\
78\end{array}$ & $\begin{array}{l}17 \\
26\end{array}$ & $\begin{array}{r}92 \\
87 \\
179\end{array}$ \\
\hline
\end{tabular}

$x^{2}=6.71, P<0.01$.

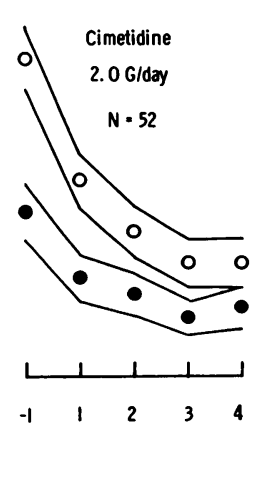

Fig. 1 The number of days (O) and nights (O) on which dyspeptic pain occurred was noted for five weeks. Observations started one week before commencement of the trial of placebo or cimetidine in the doses shown. Mean values are plotted $(N=$ number of patients in each group) and the envelopes indicate \pm 1 standard error of the mean. 

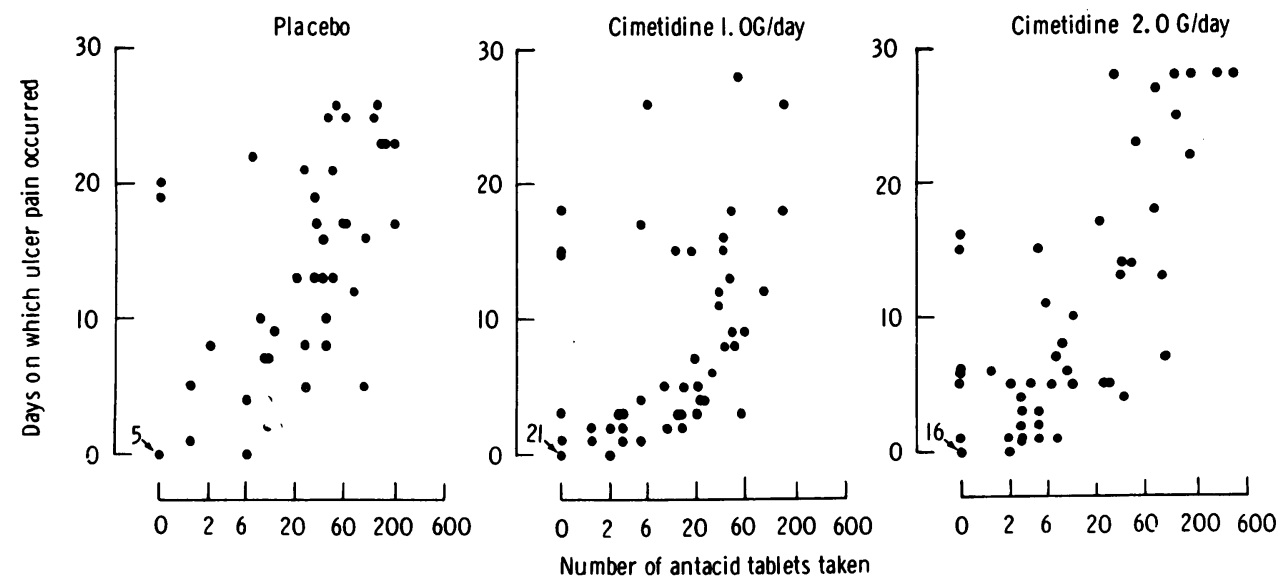

Fig. 2 This compares the number of days on which pain was reported during the four weeks of the trial with the number of antacid tablets taken (shown on a logarithmic scale). Each dot represents one patient except where otherwise indicated.

they attributed to the 'new drug'; and 43 patients on cimetidine reported 58 symptoms. Thus the incidence of symptoms was no higher in patients on cimetidine than in those on placebo. Nor was there any suggestion of a dose-related effect among patients taking cimetidine. The only symptom which appeared to be peculiar to cimetidine therapy was headache which occurred in nine patients, two at $2 \mathrm{~g} /$ day and seven at $1 \mathrm{~g} /$ day. In addition, three patients on cimetidine complained of dizziness and one of lightheadedness, symptoms which did not occur in the placebo group.

\section{HAEMATOLOGY AND BIOCHEMISTRY}

During cimetidine therapy a few patients have shown rises of serum creatinine, serum uric acid, or liver enzymes. Table 6 was constructed to see whether the few patients showing such changes were exceptional or whether they displayed to a greater degree changes which were present, though very slight, in the majority of patients. Paired-sample $t$ tests were performed for each of 13 parameters to compare the value on day 0 with those on days 14 and 28 . These comparisons were possible in only about half the potential data because of loss or clotting of some blood samples and the failure of occasional analyses. Table 6 shows the mean values ( \pm standard errors of the means) for the data analysed and indicates those cases in which the paired-sample $t$ tests were significant. Of the 78 comparisons, significant changes were found only for uric acid, and for creatinine on day 14 at the higher dose of cimetidine. No significant change occurred in the mean level of liver enzymes. An anomaly was the finding of a slight but apparently significant fall in white cells on day 14 in patients on the lower dose of cimetidine. No significant abnormalities were found on routine urine testing.

\section{Discussion}

This trial confirms the therapeutic value of cimetidine in uncomplicated duodenal ulceration. It also shows that patients are not likely to do better on $2 \mathrm{~g} /$ day than on $1 \mathrm{~g} /$ day, as the ulcer healing rates were not statistically different, being respectively 70 and $61 \%$. Symptomatic relief was also similar for the two cimetidine regimens and was rapid, occurring in the first week of treatment in both cases. These data therefore conform with the widely-held view that reduction in acid and pepsin secretion is valuable to patients with duodenal ulceration; and they justify the premise on which the dose of cimetidine was selected for clinical use. The failure of the larger dose of cimetidine to improve significantly the results of the lower dose may be explained by experiments which showed that increasing the dose above a certain level did not cause further reduction in acid secretion (Pounder et al., 1975; Blackwood and Northfield, 1977). Moreover, the results agree with those of other trials, both blind and open, in showing that with four to six weeks' treatment about $75 \%$ of duodenal ulcers heal regardless of the dose of cimetidine within the range $0 \cdot 8-2 \cdot 0 \mathrm{~g} /$ day $\left(\chi_{4}^{2}=7 \cdot 1\right.$, not significant). This is shown for 10 trials including the present study in Fig. 3 (Bank et al., 1976; Blackwood et al., 1976; Bodeman and Walan, 1976; Haggie et al., 1976; Gray et al., 1977; Hetzel et al., 1977; Peter et al., 1977; Semb et al., 1977; Moshal et al., 1977).

Variations in placebo healing rates occurred in 
Table 6 Results of laboratory tests

\begin{tabular}{|c|c|c|c|c|c|c|c|c|c|c|c|c|}
\hline & \multicolumn{4}{|c|}{ Placebo } & \multicolumn{4}{|c|}{ Cimetidine $1 \mathrm{~g} /$ day } & \multicolumn{4}{|c|}{ Cimetidine 2 g/day } \\
\hline & $N$ & Day 0 & Day 14 & Day 28 & $N$ & Day 0 & Day 14 & Day 28 & $N$ & Day 0 & Day 14 & Day 28 \\
\hline $\begin{array}{l}\text { Haemoglobin } \\
\text { g/dl }\end{array}$ & 18 & $14.2 \pm 0.5$ & $14 \cdot 2 \pm 0 \cdot 4$ & $14 \cdot 7 \pm 0 \cdot 3$ & 33 & $14 \cdot 4 \pm 0 \cdot 3$ & $14 \cdot 4 \pm 0.2$ & $14 \cdot 5 \pm 0 \cdot 2$ & 32 & $14 \cdot 5 \pm 0 \cdot 3$ & $14 \cdot 5 \pm 0 \cdot 3$ & $14 \cdot 7 \pm 0 \cdot 2$ \\
\hline $\begin{array}{l}\text { Total white cells } \\
10^{3} / \mathrm{mm}^{3}\end{array}$ & 18 & $7 \cdot 4 \pm 0 \cdot 4$ & $7 \cdot 0 \pm 0 \cdot 4$ & $6 \cdot 9 \pm 0 \cdot 4$ & 33 & $8 \cdot 2 \pm 0 \cdot 3$ & $\begin{array}{l}7 \cdot 5 \pm 0.2 \\
t=3.28 \\
P<0.01\end{array}$ & $7 \cdot 7 \pm 0 \cdot 3$ & 32 & $7 \cdot 8 \pm 0 \cdot 3$ & $7 \cdot 8 \pm 0 \cdot 3$ & $7 \cdot 5 \pm 0 \cdot 3$ \\
\hline $\begin{array}{l}\text { Neutrophils } \\
10^{3} / \mathrm{mm}^{3} \\
\text { Lymphocytes }\end{array}$ & 15 & $4 \cdot 8 \pm 0.5$ & $4 \cdot 2 \pm 0 \cdot 4$ & $4 \cdot 5 \pm 0 \cdot 3$ & 23 & $4 \cdot 9 \pm 0 \cdot 3$ & $4 \cdot 5 \pm 0 \cdot 2$ & $4 \cdot 6 \pm 0 \cdot 3$ & 24 & $4 \cdot 7 \pm 0 \cdot 4$ & $4 \cdot 7 \pm 0 \cdot 3$ & $4 \cdot 6 \pm 0 \cdot 4$ \\
\hline $\begin{array}{l}\text { Lymphocytes } \\
10^{3} / \mathrm{mm}^{3} \\
\text { Monocytes }\end{array}$ & 12 & $1 \cdot 9 \pm 0 \cdot 2$ & $2 \cdot 1 \pm 0 \cdot 2$ & $1.9 \pm 0.1$ & 24 & $2 \cdot 6 \pm 0 \cdot 2$ & $2 \cdot 2 \pm 0 \cdot 2$ & $2 \cdot 5 \pm 0 \cdot 2$ & 26 & $2 \cdot 4 \pm 0 \cdot 2$ & $2 \cdot 6 \pm 0 \cdot 2$ & $2 \cdot 4 \pm 0 \cdot 2$ \\
\hline $\begin{array}{l}\text { per mm } \text { m }^{3} \\
\text { Platelets }\end{array}$ & 12 & $420 \pm 65$ & $370 \pm 47$ & $450 \pm 73$ & 23 & $330 \pm 48$ & $440 \pm 53$ & $430 \pm 47$ & 24 & $450 \pm 64$ & $440 \pm 57$ & $420 \pm 37$ \\
\hline $\begin{array}{l}10^{3} / \mathrm{mm}^{3} \\
\text { Urea }\end{array}$ & 15 & $197 \pm 12$ & $217 \pm 34$ & $204 \pm 11$ & 27 & $234 \pm 25$ & $220 \pm 19$ & $231 \pm 17$ & 29 & $209 \pm 12$ & $221 \pm 12$ & $228 \pm 12$ \\
\hline $\begin{array}{l}\text { mmol/1 } \\
\text { Creatinine }\end{array}$ & 25 & $4 \cdot 7 \pm 0 \cdot 3$ & $\begin{array}{c}4 \cdot 2 \pm 0 \cdot 2 \\
90 \pm 2\end{array}$ & $\begin{array}{c}4 \cdot 5 \pm 0 \cdot 2 \\
96 \pm 1\end{array}$ & 38 & $5 \cdot 1 \pm 0 \cdot 3$ & $\begin{array}{l}5 \cdot 0 \pm 0 \cdot 3 \\
107 \pm 5\end{array}$ & $\begin{array}{l}4 \cdot 9 \pm 0 \cdot 2 \\
105 \pm 6\end{array}$ & 42 & $5 \cdot 3 \pm 0 \cdot 2$ & $\begin{array}{l}5 \cdot 0 \pm 0 \cdot 2 \\
115 \pm 5\end{array}$ & $\begin{array}{l}5 \cdot 2 \pm 0 \cdot 2 \\
104 \pm 4\end{array}$ \\
\hline$\mu \mathrm{mol} / \mathrm{l}$ & 22 & $104 \pm 5$ & $\begin{array}{l}t=2 \cdot 17 \\
\text { NS }\end{array}$ & $\begin{array}{l}t=1.39 \\
\text { NS }\end{array}$ & 30 & $103 \pm 6$ & $\begin{array}{l}t=0.79 \\
\text { NS }\end{array}$ & $t=0.48$ & 31 & $99 \pm 4$ & $\begin{aligned} t & =3.28 \\
\mathrm{P} & <0.01\end{aligned}$ & $\begin{array}{l}t=1 \cdot 10 \\
\text { NS }\end{array}$ \\
\hline $\begin{array}{l}\text { Uric acid } \\
\mu \mathrm{mol} / 1\end{array}$ & 18 & $337 \pm 17$ & $\begin{array}{l}308 \pm 13 \\
t=2.45 \\
\mathrm{P}<0.05\end{array}$ & $\begin{array}{l}308 \pm 13 \\
t=2.41 \\
\mathrm{P}<0.05\end{array}$ & 30 & $323 \pm 12$ & $\begin{array}{l}\quad 345 \pm 12 \\
t=1 \cdot 73 \\
\mathrm{P}<0 \cdot 1\end{array}$ & $\begin{array}{l}\quad 357 \pm 14 \\
t=2.89 \\
\mathrm{P}<0.01\end{array}$ & 39 & $319 \pm 12$ & $\begin{array}{c}354 \pm 13 \\
t=4 \cdot 13 \\
\mathrm{P}<0.001\end{array}$ & $\begin{array}{c}350 \pm 12 \\
t=4.10 \\
\mathrm{P}<0.001\end{array}$ \\
\hline $\begin{array}{l}\text { Bilirubin } \\
\mu \mathrm{mol} / 1 \\
\text { Aspartate trans. }\end{array}$ & 19 & $10 \cdot 3 \pm 1 \cdot 0$ & $7 \cdot 9 \pm 0 \cdot 6$ & $10 \cdot 6 \pm 1 \cdot 1$ & 29 & $11 \cdot 2 \pm 1 \cdot 3$ & $10 \cdot 5 \pm 1 \cdot 0$ & $11 \cdot 1 \pm 1 \cdot 3$ & 34 & $10 \cdot 7 \pm 0.9$ & $11 \cdot 6 \pm 0 \cdot 9$ & $11 \cdot 4 \pm 1 \cdot 0$ \\
\hline $\begin{array}{l}\text { IU/1 } \\
\text { Alanine trans. }\end{array}$ & 22 & $20 \pm 2$ & $21 \pm 3$ & $21 \pm 3$ & 37 & $22 \pm 2$ & $23 \pm 2$ & $23 \pm 2$ & 39 & $29 \pm 4$ & $29 \pm 3$ & $31 \pm 4$ \\
\hline $\begin{array}{l}\text { IU/1 } \\
\text { Alkaline phosphatas }\end{array}$ & se $^{13}$ & $15 \pm 2$ & $16 \pm 2$ & $16 \pm 2$ & 21 & $16 \pm 2$ & $15 \pm 2$ & $17 \pm 2$ & 23 & $27 \pm 7$ & $25 \pm 4$ & $30 \pm 6$ \\
\hline $\mathrm{IU} / \mathbf{1}$ & 19 & $48 \pm 5$ & $51 \pm 6$ & $48 \pm 4$ & 34 & $50 \pm 6$ & $52 \pm 7$ & $47 \pm 6$ & 34 & $50 \pm 5$ & $50 \pm 5$ & $48 \pm 4$ \\
\hline
\end{tabular}

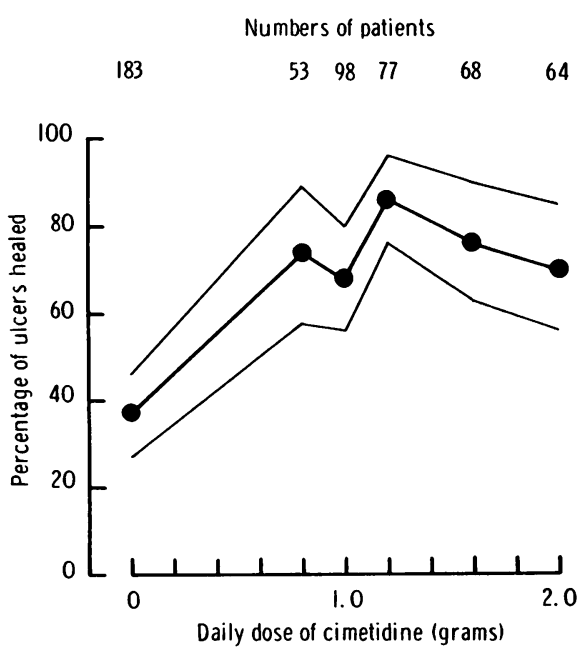

Fig. 3 Percentage of duodenal ulcers healing in four to six weeks in patients receiving placebo or cimetidine. The numbers of patients studied at each dose of cimetidine are shown at the top. The envelope shows $99 \%$ confidence limits for the proportions healing at each dose. (Data derived from this study and nine others.)

these trials $\left(\chi^{2}=19 \cdot 2, \quad \mathrm{P}<0.005\right)$ which are not explained; but it will be noted that very few of our patients took large amounts of antacid. Had they done so, the placebo healing rate might have been higher.

Tobacco consumption may be an aetiological factor in the development of peptic ulcer, but information is lacking on the effect of smoking on the healing of duodenal ulcers; the present data suggest that if there is an effect, it cannot be very marked. This is also true for all the other variables we looked at; there was, for example, no evidence that cimetidine was less (or more) effective in patients with long or short histories. Our data do nothing to elucidate the relation between duodenal ulceration and pain; rather they emphasise the paradox that ulcers can be painless, and ulcer-type pain can occur in the absence of demonstrable ulceration.

Headache was the only unwanted symptom which one might reasonably suspect to have been caused by cimetidine. Perhaps 'dizziness' and 'lightheadedness' were attempts to describe the same symptom. In any case these symptoms were mild, and occurred in only $10 \%$ of patients on cimetidine.

Isolated abnormal values of creatinine, urate, and liver enzymes have been reported in patients on cimetidine-as, for example in a preliminary account of this trial (Proceedings of 2nd International Symposium on Histamine $\mathrm{H}_{2}$-Receptor Antagonists, Excerpta Medica, 1977). This method of recording is useful for picking out patients who display marked 
changes, but it might fail to demonstrate alterations which were consistent, though slight. Such changes can be shown by comparing, in paired-sample tests, the value of a parameter on day 0 with that on day 14 and on day 28. This was done in all cases in which data were complete and, as shown in Table 6 , the abnormalities discovered were those expected. Thus, a systematic change in creatinine values was seen only with the larger dose of cimetidine, and only at day 14. These very slight changes are similar to those originally reported (Haggie et al., 1976). Although concentrations of aspartate and/or alanine transaminase rose above the normal range in 18 patients receiving cimetidine, no systematic change in either enzyme was found. These results fail to confirm the systematic change in these enzymes reported by Blackwood et al. (1976). Rises in serum transaminase concentrations in our patients were not accompanied by other changes indicative of hepatoxicity; in particular no patient developed clinical or subclinical jaundice.

On the other hand, a slight but consistent rise in serum uric acid was observed in patients taking cimetidine. Although the average change was no greater with the higher dose of cimetidine, it was more consistent and therefore more significant statistically. Many drugs are known to influence urinary excretion of uric acid; the changes found in this trial are neither large nor progressive over the period tested, so it is unlikely that they will prove of clinical significance. We have no explanation for the slight fall in serum uric acid which occurred in placebo patients.

The slight (but apparently significant) fall in total white cells seen at day 14 with the lower dose of cimetidine is probably the sort of anomalous result to be expected with a definite frequency when multiple statistical tests are applied to a large body of data. It is notable that no such effect was seen with the larger dose of cimetidine. Also, the change was not due to a fall in any one of the three main types of white cell.

We conclude that cimetidine in a dose of $200 \mathrm{mg}$ three times a day after meals and $400 \mathrm{mg}$ at nights represents a satisfactory regimen for the management of uncomplicated duodenal ulcer; even at double this dose neither serious side-effects nor evidence of toxicity was found. On the other hand, a considerable proportion of patients did not heal their ulcers, even on the higher dose of cimetidine. Since it is now known that many patients relapse after both short and longer courses of cimetidine (Bodemar and Walan, 1978; Gudmand-Høyer et al., 1978), it will be necessary to study the course of duodenal ulcer disease when treatment is maintained for years.
The authors are indebted to the departments of haematology and biochemistry at each of the participating hospitals, and to departments of pharmacy for dispensing the trial medicines. The trial was coordinated by the Clinical Research Group, Smith Kline and French Laboratories, Welwyn Garden City, to whom thanks are due.

\section{References}

Bank, S., Barbezat, G. O., Novis, B. H., Ou Tim, L., Odes, H. S., Helman, C., Narunsky, L., Duys, P. J., and Marks, I. N. (1976). Histamine $\mathrm{H}_{2}$-receptor antagonists in the treatment of duodenal ulcers. South African Medical Journal, 50, 1781-1785.

Blackwood, W S., Maudgal, D. P., Pickard, R. G., Lawrence, D., and Northfield, T. C. (1976). Cimetidine in duodenal ulcer: controlled trial. Lancet, 2, 174-176.

Blackwood, W. S., and Northfield, T. C. (1977). Nocturnal gastric acid secretion: Effect of cimetidine and interaction with anticholinergics. In Cimetidine: Proceedings of the 2nd International Symposium on Histamine $\mathrm{H}_{2}$-Receptor Antagonists (International Congress Series, 416), pp. 124-130. Edited by W. L. Burland and M. A. Simpkins. Excerpta Medica: New York; Amsterdam.

Bodemar, G., and Walan, A. (1976). Cimetidine in the treatment of active duodenal and prepyloric ulcers. Lancet, 2 , 161-164.

Bodemar, G., and Walan, A. (1978) Maintenance treatment of recurrent peptic ulcer by cimetidine Lancet, 1, 403-407.

Gray, G. R., McKenzie, I., Smith, I. S., Crean, G. P., and Gillespie, G. (1977). Oral cimetidine in severe duodenal ulceration: a double-blind controlled trial. Lancet, 1, 4-7.

Gudmand-Høyer, E., Birger Jensen, K., Krag, E., RaskMadsen, J., Rahbek, I., Rune, S. J., and Wulff, H. R. (1978). Prophylactic effect of cimetidine in duodenal ulcer disease. British Medical Journal, 1, 1095-1097.

Haggie, S. J., Fermont, D. C., and Wyllie, J. H. (1976). Treatment of duodenal ulcer with cimetidine. Lancet, 1, 983-984.

Hetzel, D. J., Taggart, G. J., Hansky, J., Hecker, R., and Shearman, D. J C. (1977). Cimetidine in the treatment of duodenal ulcer. Medical Journal of Australia, 1, 317-319.

Interim Report of Multicentre Double-blind Trial. (1977). The effect of cimetidine on duodenal ulceration. In Cimetidine: Proceedings of the 2nd International Symposium on Histamine $\mathrm{H}_{2}$-Receptor Antagonists (International Congress Series, 416), pp. 260-271. Edited by W. L. Burland and M. A. Simpkins. Excerpta Medica: Amsterdam.

Moshal, M. G., Spitaels, J. M., and Bhoola, R. (1977). Treatment of duodenal ulcers with cimetidine. South African Medical Journal, 52, 760-763.

Peter, P., Fritsch, W. P., Nieschlag, E., Wienbeck, M., and Strohmeyer, G. (1977). Cimetidine in the treatment of duodenal ulcer. In Cimetidine: Proceedings of the 2 nd International Symposium on Histamine $\mathrm{H}_{2}$-Receptor Antagonists (International Congress Series, 416), pp. 254-259. Edited by W. L. Burland and M. A. Simpkins. Excerpta Medica: Amsterdam.

Pounder, R. E., Williams, J. G., Milton-Thompson, G. J., and Misiewicz, J. J. (1975). Twenty-four hour control of intragastric acidity by cimetidine in duodenal ulcer patients. Lancet, 2, 1069-1072.

Semb, L. S., Berstad, A., Myren, J., Chr. Foss, J., Carlsen, E., and Kruse-Jensen, A. (1977). A double-blind multicentre comparative study of cimetidine and placebo in short-term treatment of active duodenal ulceration. In 
Cimetidine: Proceedings of the 2nd International Symposium on Histamine $\mathrm{H}_{2}$-Receptor Antagonists (International Congress Series, 416), pp. 248-253. Edited by W. L.
Burland and M. A. Simpkins. Excerpta Medica: Amsterdam.

\section{The December 1978 Issue}

\section{THE DECEMBER 1978 ISSUE CONTAINS THE FOLLOW PAPERS}

\section{Editorial note}

Re-evaluation of the technique of organ culture for studying gluten toxicity in coeliac disease $H$. P. HAURI, M. KEDINGER, K. HAFFEN, H. GAZE, B. HADORN, AND W. HEKKENS

Influence of inflammatory bowel disease on intestinal microflora M. R. B. KEIGHLEY, Y. ARABI, F. DIMOCK, D. W. BURDON, R. N. ALLAN, AND J. ALEXANDER-WILLIAMS

Vitamin $\mathrm{B}_{12}$ binding protein as a tumour marker for hepatocellular carcinoma S. P. KANE, I. M. MURRAYLYON, F. J. PARADINAS, P. J. JOHNSON, R. WILLIAMS, A. H. ORR, AND J. KOHN

Kinetics of ${ }^{14} \mathrm{C}$-glycocholic acid clearance in normal man and in patients with liver disease I. T. GILMORE AND R. P. H. THOMPSON

Effect of glucagon and pentagastrin on gastric mucosal potential difference in man A. TARNAWSKI, K. J. IVEY, J. E. MCGUIGAN, AND J. ENGLAND

Lower oesophageal sphincter response to intravenous infusions of pentagastrin in normal subjects, antrectomised and achalasic patients E. CORAZZIARI, C. POZZESSERE, S. DANI, F. ANZINI, AND A. TORSOLI

Renal clearance of pancreatic and salivary amylase relative to creatinine in patients with chronic renal insufficiency J. B. KEOGH, K. F. MCGEENEY, M. I. DRURY, T. B. COUNIHAN, AND MARY D. O'DONNELL
Oral prednisone for chronic active liver disease: dose responses and bioavailability studies $M$. URIBE, S. W. SCHALM, W. H. J. SUMMERSKILL, AND V. L. W. GO

\section{Clinical trials}

Comparative trial of sulphasalazine and oral sodium cromoglycate in the maintenance of remission in ulcerative colitis M. W. DRONFIELD AND M. J. S. LANGMAN

Controlled trial of disodium cromoglycate in chronic persistent ulcerative colitis N. A. BUCKELL, S. R. GOULD, D. W. DAY, J. E. LENNARD-JONES, AND A. M. EDWARDS

Comparison of bran, ispaghula, and lactulose on colon function in diverticular disease M. A. EASTWOOD, A. N. SMITH, W. G. BRYDON, AND J. PRITCHARD

\section{Case report}

Gamma heavy chain disease simulating alpha chain disease S. W. BENDER, F. DANON, J. L. PREUD'HOMME, H. G. POSSELT, P. ROETTGER, AND M. SELIGMANN

\section{Progress reports}

Diabetes and the gut J. H. B. SCARPELlo AND G. E. SLADEN

Maintenance of anal continence: a review of pelvic floor physiology v. A. DICKINSON

Notes and activities; Books

Index to Volume 19

Copies are still available and may be obtained from the PUBLISHING MANAGER, BRITISH MEDICAL ASSOCIATION, TAVISTOCK SQUARE, LONDON WC1H 9JR, price $£ 3.50$, including postage 